\title{
17 The Right to Education for Migrant Children in Thailand: Liminal Legality and the Educational Experience of Migrant Children in Samut Sakhon
}

\author{
Kamowan Petchot ${ }^{1}$
}

\begin{abstract}
For decades, Thailand has experienced an influx of a large number of migrants from Myanmar who have come in search of better economic opportunities. This influx has led to a sizeable migrant population residing in Thailand, of which children make up a significant percentage. Providing education for large numbers of migrant children has become a matter of national concern, both because of Thailand's international human rights obligations and as a matter of national security. Responding to these concerns, the government of Thailand has adopted a policy of providing free and compulsory education for every child within its territory, including migrant children. However, despite the efforts of the Thai government to provide education for all, many migrant children are still unable to benefit from this policy.

In this chapter, the challenges of realizing the right to education for migrant children in Samut Sakhon, a coastal province in central Thailand, are studied. Schools are regarded as institutional duty bearers that are obliged, on behalf of the state, to fulfil their legal obligation in terms of Thai government policy. These obligations emanate from the Convention on the Rights of the Child, to which Thailand is a state party. In addition, the research analyses the precarious status of migrant children. The concept of 'liminal legality' is used to conceptualize the in-between status of migrant children and families, and to illustrate how this liminal status shapes the opportunity structure of migrant children in education by influencing household decision-making. In this chapter, it is argued that addressing the liminal status of migrants is essential in addressing not only the issue of migrant children's education, but also that of their incorporation into Thai society in general.
\end{abstract}

Keywords: Burmese migrants, migrant children, right to education, liminal legality, Thailand.

\subsection{Introduction}

Since the I980s, the expansion of Thailand's economy has created a large national demand for labour, and especially for unskilled labour. Unskilled work has been shunned by local Thai workers, partly because of improvements in the level and availability of basic education through to secondary school. This has resulted in Thai workers moving from semi-skilled to skilled jobs. In addition, the preference of Thais to work in

1 Kamonwan Petchot (Thailand) holds an MA in Development Studies from the International Institute of Social Studies (ISS) of Erasmus University Rotterdam. She is currently a consultant to the Asia Pacific Forum on Women, Law and Development (APWLD). the service sectors as well as a decline in the birth rate has resulted in an acute domestic labour shortage, especially in labour-intensive industries (Chantavanich 2007a: I). Consequently, Thailand has become a destination for many migrants from neighbouring countries throughout South-East Asia, and in particular from Myanmar, Cambodia, and Laos, who fill the gap in unskilled jobs. A sizeable community, migrants in Thailand have fuelled the country's economic growth. According to a report by the International Labour Organization (ILO), out of thirty-six million Thai workers in 2007 , five per cent or I.8 million were migrants, and their contribution to the Thai gross domestic product (GDP) was estimated at I.25 per cent or US\$2 billion. The number of migrants and the 
range of occupations in which they have been employed has further expanded (Martin 2007: xi-xii).

Children make up a significant percentage among those migrants who come to Thailand. Article I of the UN Convention on the Rights of the Child (CRC I989) defines a child as "every human below the age of I8 years unless under the law applicable to the child, majority is attained earlier”. A 2008 report by the International Organization for Migration (IOM) estimated that there were 200,000 migrant children under the age of I7 years in Thailand (IOM 2008: I84). Migrant children in Thailand are a heterogeneous group, differentiated by age, ethnicity, their legal status, and the patterns of mobility of their parents. For the purposes of this chapter, migrant children can be divided into those who are (I) migrants themselves who came to Thailand without their parents in search for work; (2) those who accompanied their family, and (3) children who were born to migrant parents in Thailand (Huguet/Punpuing 2005: I24, Thu 2006: I4).

From the perspective of the Thai government, providing education to migrant children is a response to its international obligations under the UN Convention on the Rights of the Child (CRC), which obliges Thailand to provide for all children, including the children of migrants, with the right to education. It is regarded by the government as a measure to ensure national security in the long term, since a large number of uneducated migrant children without access to formal employment could join in illegal activities that would harm national security, such as drug trafficking or the sex industry. There is much public concern that the lack of access to education by migrant children can lead to their marginalization and prevent their assimilation into Thai society. Without access to education, migrants remain an uneducated underclass vulnerable to exploitation and illegal activities. This is confirmed by Caouette, who argues thatmigrants' cultural and economic marginalization may lead to drug trafficking or human trafficking for labour or sexual exploitation in the sex industry (Caouette 200I: 92, I07).

As a state party to the CRC, Thailand is obliged to respect, protect, and fulfil the right to education for all children, including migrant children. Article 28 of the CRC provides that all children have a right to education. Responding to this international obligation, the Thai government has adopted various policies to ensure universal education for every child within its territory. The 'Education for All' campaign, which was supported by the United Nations Educational, Scien- tific and Cultural Organization (UNESCO), was adopted by Thailand in I990 (MFA 20II). In 2004, the Office of Education Council (OEC) created the 'Education Provision for Disadvantaged Children' (MFA 20II; ILO/OEC 2008: II). In addition, the 'Education for All Cabinet Resolution' of 2005 provided for universal access to education for all children in Thailand, regardless of their nationality or legal status (MFA 20II; ILO/OEC 2008: II).

However, there is a gap between law and implementation. This is evidenced through the very low number of migrant children who actually enrol in school. According to the Foundation for Rural Youth (FRY), a non-governmental organization (NGO) that promotes access by migrant children to Thai public schools, Thailand has accepted less than sixteen per cent of registered migrant children into its education system. In some areas, such as Bangkok, the situation is critical, with fewer than four per cent of migrant children enrolled in schools. ${ }^{2}$

Studies of access to education by migrant children have pointed to three interconnected problem areas, namely policy issues, the school system, and problems at the household level (Thu 2006: I8). At the level of policy, the 2005 'Education for All Cabinet Resolution' requires that migrant children be afforded the same rights as Thai children, including government funding. However, schools cannot receive government funding for migrant children who are undocumented (Thu 2006: 60). Therefore, schools bear the financial burden of accepting the children of undocumented migrants. This runs contrary to the government policy of offering education to all children, irrespective of their nationality or documented status.

At the level of the school system, legal consciousness among school administrators, or the way in which they perceive and interpret their obligations as stated by law, also appears to be a major issue. Amanda Bissex, chief of the child protection section of the UN Children's Fund (UNICEF) Thailand has pointed out that "access to education for migrant children is impeded by understanding of the cabinet decision at the local level" (Irinnews 2009). Thu's study (2006) revealed that the government budget was misused, for example by using the per-head budget, which is aimed directly at students to cover their edu-

2 Nicola Hoyne, 20II: "Thailand: Education desperately needed for migrant and stateless children"; at: <http:// www.minorityvoices.org/news.php/fr/693/thailandeducation-desperately-needed-for-migrant-and-statelesschildren> (accessed I5 June 20II). 
cational costs (e.g. uniforms, shoes, and books), and for other school expenditure (e.g. electricity and water). Consequently, many schools did not receive the supporting budget as stated in the Cabinet Resolution (Thu 2006: 60).

At the household level, factors that affect the educational opportunities of migrant children are the attitude of migrant parents towards education in general and the Thai educational system in particular. Migrant parents with a positive attitude towards education tend to keep their children in school for a longer period of time. Other factors include the direct costs (e.g. fees, books, clothes) and indirect costs (e.g. child labour) of attending school, an uncertain future in Thailand, lack of information about Thai education, gender, the duration of their stay in Thailand, and proficiency in the Thai language, all of which can have negative impacts on migrant children's opportunities for pursuing education (Thu 2006: I8).

This study explores the challenges of accessing education, faced by the children of migrants in Thailand. The rights of migrants derive from the international legal obligations of the state, although an explicit, national recognition of their legal status is important in defining who is entitled to what level of rights protection. Migrant children are not entitled to the same rights and protection as those who are citizens. The law requires that each child, including migrant children, residing on Thai territory is legally entitled to the right to education; however, there are some legal gaps or difficulties for migrant children in obtaining an education. Their presence in Thailand is only temporarily legal or even illegal in some cases but they are legally entitled to education, while the future of their career or status in Thailand remains unclear. The in-between or 'liminal' legal status of migrant children makes it difficult for the state to realise the right to education. Furthermore, the framing of children's education as an issue of human security (reduced to the idea of the costs and benefits of providing education) can be confused with matters of national security (viewing migrants as a potential threat), which may generate fear and mutual suspicion among members of a community and further undermine efforts to provide education for migrant children. This is a grey area of the law. Migrant children's experiences are shaped in a different way from the experiences of other groups of children.

\subsection{Methods and Scope of Study}

The research project used qualitative methods. Data was collected through different methods, including documentary research, semi-structured interviews, and field observation. My main method was semistructured interviews with three groups of informants: (I) migrant students, (2) migrant parents, and (3) teachers and educators. Fifteen informants from each group (forty-five in total) were selected from three schools (two public schools and an NGO learning centre). The community of Samut Sakhon in central Thailand was selected as a field for research study because of the large number of Burmese migrant children who live there; in addition, the local governor has made an effort to provide education for migrant children in the community. Based on a case study of this community, this chapter documents how Thailand deals with the education of migrant children.

\subsection{Thai Policy on Labour Migration}

Due to a domestic labour shortage in Thailand from the late I980s until the early I990s, the business sector asked permission to employ foreign workers in order to overcome their labour shortage. In 1992, the Thai government developed an immigration policy for unskilled labour migrants, mostly directed towards the fishing, construction, agricultural, and other industrial sectors.

In Thailand, the rights of workers and the obligations of employers are covered by the Labour Protection Act of 1998 (B.E.254I), which deals with working hours, holidays, notice, overtime, and sick pay. However, as Muntarbhon (2005: I3) argued, the "national law with the greatest impact on migrant workers are not the labour laws themselves but the national immigration law". Immigration policies governing migrant workers' lives in Thailand rely on two major acts, the Foreign Employment Act 2008 (B.E.255I) and the Immigration Act 1979 (B.E.2522). The latter states that unauthorized entry or breach of immigration law or both is illegal and may lead to deportation or other penalties or both. However, Section I7 gives the Ministry of the Interior some flexibility to exempt irregular migrants from being deported if they present themselves for registration. Additionally, the employment of migrant workers is regulated by the Foreign Employment Act 2008, which requires that an alien must have a work permit and that aliens are allowed to work only in activities designated by law or by the 
relevant governmental authority (i.e. the Ministry of Labour) (Muntarbhon 2005: 13).

Thailand had never allowed the employment of unskilled foreign workers in the country before; its existing legal framework did not provide clauses for such initiatives, so the government decided to use a cabinet resolution as the mechanism to establish a new legal framework. The cabinet resolution is an ad hoc type of policy formulation based on the belief that the employment of migrant workers would be a temporary event and the situation would change after some years (Chantavanich 2007a: I-2).

This belief in the 'temporariness' of migrant labour has proven to be misplaced. Many economic sectors in Thailand have relied continuously on migrant workers for more than three decades and there appears to be no prospect that Thai workers will return to these labour-intensive jobs. On the contrary, a research study suggested that the structural dependence on migrant workers tends to persist in the medium- to long-term since there is little evidence of alternatives such as a mechanization or re-structuring of the national workforce to attract Thai workers (Martin 2004: 3).

\subsubsection{Administration of Thai Labour Migration Policy}

The main administrative bodies involved in migrant management in Thailand are the Ministry of the Interior (MOI) and the Ministry of Labour (MOL). The MOI manages the regularization of migrants through civil registration and issues a thirteen-digit identification (ID) number, which grants migrants a temporary residence. The MOI's primary concern has been to protect national security, and therefore it has supported strict migrant policies, from confining migrants to the employers with whom they had registered to restrictions on their freedom of movement (Pollock/Pearson/Kusakabe 2009: 3-4). The MOI introduced policies that assumed that the need for migrant labour in Thailand was temporary. Consequently, migrant workers are 'working migrants' who will eventually return to their countries of origin.

The MOL is responsible for issuing work permits, which will allow migrant workers to legally obtain employment in Thailand. The primary concern of the MOL is the demand for migrant workers to meet the country's domestic labour shortage, and since the Ministry works directly with the domestic labour market and business sectors, the MOL recognizes the importance of migrant workers and the prospect that
Thailand will continue to depend on migrant workers in many sectors in the future. Thus, the policies of the MOL tend to be more generous, and it has worked with other related agencies on policies to grant welfare assistance and other forms of social and legal protection to migrant workers, including health care and decent working conditions, although these policies are limited to workers only and do not necessarily imply protection for the children of migrants (Rukumnuaykit 2009: 27).

The first migrant workers registration programme was introduced through a cabinet resolution in 1992 that allowed registered migrants to temporarily work in Thailand instead of facing deportation. Initially, the registration was limited only to Burmese migrants and to certain types of jobs (fishing, construction, agricultural, and some industries) in particularly designated provinces (Chantavanich 2007a: 1). A big demand from the business sector for migrant workers pushed the government to introduce additional categories for registration, which gradually expanded to migrants from Cambodia and Laos and to additional provinces, and also gradually expanded the number of job types to seven, then eleven, then forty-seven, and then to eighteen sectors in five industries, before it eventually expanded to all types of jobs and sectors in 200I (Chantavanich 2007b: 2, 4).

Later, in an attempt to manage migration differently, the registration shifted from an area-based system to one that was area- and quota-based. The government limited the number of registered migrants following a recommendation by scholars (Chantavanich 2007b: 5). However, this amendment has been of limited relevance since the number of registered workers has been lower than the quota. This was due to the fact that many workers have been employed in sectors that were not permitted to hire migrants. Nevertheless, some employers have been unwilling to pay high registration costs, although they have avoided prosecution by paying bribes to the police (Chantavanich 2007a: 6).

In 200I, the Thai government changed its policy again to permit an open registration nationwide in all occupations, without any limiting quotas. The intention was to 'regularize' all underground irregular migrant workers, so that the government could have an accurate figure of the number of migrants to guide future policy measures. The registered number of migrants in $200 \mathrm{I}$ was 568,000 , the highest number ever recorded, before the number dropped to 409,339 in the following year when the registration programme was renewed (Rukumnuaykit 2009: 20). At the same 
time, the government concluded memoranda of understanding (MOUs) with Myanmar, Laos, and Cambodia to legalize migrant workers, based on a government-to-government recruitment of migrant workers for specific periods of employment in Thailand. Placing conditions for this registration was intended to motivate the workers to return home after the completion of employment, although the MOUs also covered matters of labour protection and dispute settlement, and measures aimed at eliminating illegal employment (Chantavanich 2007a: 7).

In 2004, another major shift in migrant policy occurred which required that migrant workers, their dependents, and their employers must all be registered. Migrant workers and their dependents were to receive a thirteen-digit ID number for better migration management. These IDs were only valid for one year, however, and since then there has been no systematic effort to register migrants, other than those applying for work permits. In addition, the 20 II work permit registration with the MOL was opened for dependents (family and children) of migrant workers to apply for a temporary status.

In short, most laws and policies regulating migrants have been concerned with the working conditions, wages, and welfare of migrant workers. There has never before been an immigration law or policy concerning migrant children in Thailand. Furthermore, the government of Thailand sees a key linkage between immigration law, national security, and national policy, with national security in particular shaping the application of the Immigration Act. Consequently, a series of cabinet decisions since 1992 have resulted in a 'half-open door' policy towards migrant workers (Muntarbhon 2005: I3).

\subsubsection{Thai Policy on Migrant Children}

Since the early 2000 s, the government has responded to the concerns raised by international organizations (e.g. ILO) over migrant children with regard to child trafficking and exploitation of migrant child labour in the commercial sexual industry, the fishery industry, and seafood processing factories. ${ }^{3}$ At the same time, the increasing numbers of migrant children raised challenges of integration which were perceived by the Thai government as a potential threat to national

3 See: United States Department of Labor, 20I2: Thailand: Incidence and Nature of Child Labour; at: <http:// www.dol.gov/ilab/media/reports/iclp/tda2004/thailand. htm> (accessed I5 May 20I2). security (ILO/OEC 2006: I, 2008: 8). The Thai government and international agencies (e.g. ILO and Save the Children) regarded education as the best solution for reducing poverty and child labour. Education was also regarded as assisting in the integration of migrant children into Thai society, thereby reducing the (perceived) national security threat.

In addition, based on the norms of international treaties to which Thailand is a party, the Ministry of Education (MOE) introduced the 'Education for All' policy, which aimed to expand universal education in order to reach all children from every group in society, including migrant children. In 2005, based on the 'Education for All' policy, the MOE began working in cooperation with other relevant stakeholders to provide education for migrant children, irrespective of whether or not they were documented. This included cooperation with the Ministry of Interior (MOI), which started issuing a civil status that granted temporary residence to migrant children. However, as there was no clear and coherent policy in place for migrant workers in Thailand, and as each organization involved in migrant management had different interests and agendas, the possibility for misunderstandings between policies at the local and national levels was high.

Thus, while the Thai government openly recognized the right to education, at the same time the restrictions of Thai immigration law meant that it was almost impossible to acquire a permanent residence, let alone citizenship. Hence, the migrant assimilation process has relied greatly on how migrants manage to deal with their precarious status.

\subsubsection{Migrant Labour in Samut Sakhon Province}

The Samut Sakhon province, has experienced rapid economic growth, which has in turn expanded the labour market in three key sectors (fishery, industry, and agriculture), but this work has been unattractive to Thai workers. A high and growing demand for labour, coupled with inadequate local labour, created an acute labour shortage, paving the way for migrant workers from neighbouring countries to fill the gap. Half of the workers in these sectors are now migrants. Responding to the pressure from the private sector for a sustainable labour supply, in 1992 the Thai government eased the procedure for registration of undocumented migrants from Myanmar, Laos, and Cambodia to temporarily work in the province. Initially the law allowed them to work only in fishery 
and fishery-related factories, construction, farming, and domestic service, before it gradually expanded to nineteen other sectors by 2009 (Chantavanich 2007a: 2; Thai Cabinet Resolution of 26 May 2009). The actual number of migrants in Samut Sakhon, taking into account unregistered migrants, is estimated to be 200,000, compared to the local Thai population of 543,302 (ILO/OEC 2006: 5; Thu 2006: 3I).

Samut Sakhon is also an attractive destination for migrant workers due to relatively high wage levels compared with other provinces. As of I April 20I2, the minimum wage in Samut Sakhon is 300 baht per day, whereas in other provinces with a high concentration of migrant workers such as Tak, Chiang Rai, and Ranong, the minimum wage is 226, 232, and 259 baht respectively. ${ }^{4}$ However, undocumented workers often receive less than the minimum wage, and have no negotiating power (Martin 2004: 20). Even when workers are legally documented, they still have very little negotiating power over their wages as the registration system ties the migrants to the employers with whom they have registered. Migrant workers who quit or leave without the employer's or the authority's permission will immediately lose their work permits, a situation that leaves them with little room for wage negotiation.

The majority of migrant workers in Samut Sakhon are from Myanmar. Out of 76,059 registered migrants in 2008, 75,6I4 (99.4I per cent) were from Myanmar while 378 ( 0.5 per cent) were from Laos, and 67 (0.09 per cent) from Cambodia. Among the various ethnic groups that enter Thailand, Mon and Burmese are the majority. Samut Sakhon also has old Mon-Thai communities who migrated to Thailand a long time ago and are now Thai citizens of Mon ethnic origin. Mon is an ethnic group from Myanmar who have a long history of migration to Thailand because of an ongoing ethnic conflict in Myanmar. Their first migration dates back to as early as the sixteenth century. The majority of migrant workers are concentrated in the Muang Samut Sakhon district, and especially in Mahachai, where seafood processing and fishery-related factories are located. As will be argued next, this situation for migrants in Thailand represents a clear example of 'liminal legality' or a 'segmental assimilation', where the outcome of the assimilation varies due to personal and interpersonal factors.

4 Department of Employment, 20I2: Ministry of Labour Statistics, Government of Thailand; at: <http://www. doe.go.th/Page/interesting/interesting3.html> (accessed 28 June 20I2).

\subsection{Liminal Legal Status}

Legal status has been recognized by scholars as one of the most essential aspects of migrants' lives. Immigration law governs and shapes vital spheres of migrants' existence, from health care, vulnerability in the streets, the ability to combat domestic violence, and access to the labour market and wage levels, to their identity, self-recognition, and, more importantly, incorporation in the receiving country (Menjivar 2006: 1000). The impact of legal status on the lives of migrants has been stressed as very influential, to the point that it creates different classes of immigrants with different rights and privileges. These differences in turn contribute to the experiences faced by migrants from different legal categories (Freeman 2004: 950).

In their study on 'segmented assimilation', Portes and Zhou (1993) pointed to the different contexts of reception in the lives of migrants, which may consequently lead them in different directions. According to Menjivar, migrants do not form homogeneous groups and they have different access to resources (economic, social, and legal status) as well as to conditions in destination areas. Therefore, the outcomes of the integration of migrants into the host society vary. Conditions in the receiving country include personal factors such as skills, and extra-personal factors such as immigration law and access to the labour market, which work together to shape the opportunity structure for migrants in a receiving country (Menjivar 2006: I002). Immigration law determines which legal categories the migrants belong to (regular/irregular or documented/undocumented), as well as the status and participation of migrants in society; these are closely linked to their entitlement to resources, 'with little to share with others' (Menjivar 2006: IO23). Immigration law can be a constraining factor affecting the opportunities of migrants in the labour market by determining who can or cannot do certain kinds of jobs and for how long. For migrant workers in Thailand, immigration law strictly governs their work conditions. Moreover, immigration law and legal status also govern the interaction of migrants with welfare and cultural regulations (Freeman 2004: 950).

Legal status is closely linked to the concept of citizenship, which not only forms the domestic legal basis for access to individual rights, but also frames the social obligations between the individual and the state. Citizenship furthermore shapes immigrants' membership in society and their understanding of their place in it (Menjivar 2006: I003). As noted by Calavita, "[t]he immigrant is a stranger, physically 
present but not a member of a community" (Calavita I998: 40I). The legal status of migrants is conventionally divided in a binary way between regular and irregular or documented and undocumented. However, as globalization has brought about changing patterns of movement and migration as well as variable migration policies in different contexts and historical periods, the boundaries of legal categories between the black area of illegality and the white area of legality have become blurred. A new category of immigration status has emerged in the grey area in between these two conventional categories. This in-between status has been explored by different scholars, and referred to variously as "liminal legality" (Menjivar 2006), "permanent temporariness" (Bailey/Wright/Mountz/Miyares 2002: 125), "legal non-existence" (Coutin 2002: 34, 47), "precarious status" and "less-than-full status" (Goldring/Berinstein/Bernhard 2009: 240).

Using the concepts of "liminality" and "legal nonexistence", Cecilia Menjivar developed the concept of "liminal legality" to explain the social impact of Central American immigrants' uncertain status. Victor Turner's concept of "liminality" was used to conceptualize the "becomingness-state" or the transitional period between two relatively fixed or stable conditions (Turner 1967: 93). Susan B. Coutin's concept of "legal non-existence" captured the experiences of undocumented Central Americans as being "physically present and socially active but lacking legal recognition” (Menjivar 2006: I008). Undocumented migrants living in legal non-existence fall under a state of subjugation, which makes them "vulnerable to deportation, confinement to low wage jobs and denial of basic human needs, such as decent housing, education, food and healthcare" (Menjivar 2006: I008). Coutin stresses the negative impact of legal non-existence as an "erasure of rights and personhood thus making violence against people in this condition not only legitimate but sometimes even required" (Coutin, cited in Menjivar 2006: I008). Without legal recognition by the state, the rights of people who live under this situation become ambiguous and are usually violated (Coutin 2000, cited in Menjivar 2006: I008).

Liminal legality is therefore characterized by its ambiguity; it is neither a regular nor irregular status but may have characteristics of both. It is neither onedimensional nor a linear process; it is not simply a changing phase from undocumented to documented status - the transition is never complete as the migrants' legal status usually fluctuates (Menjivar 2006: IOOI). Migrants who register and become regularized in Thailand are granted temporary residence and work permits, which are generally valid for no more than two years. Their status is thus one of temporary legality. In addition, migrants may return to an irregular (undocumented) status in different ways: when their temporary status ends, when their work permits expire, or if they violate the immigration law and regulations such as changing employers without either the employer's or the authority's permission, or when migrant workers leave the province in which they are registered without authorized permission (Vasuprasat 20I0: 20).

\subsubsection{Liminal Legality and Migrant Children's Access to Education}

Migrant children in Thailand are a heterogeneous group, differentiated by age and ethnicity, as well as by the legal status and the patterns of mobility of their parents. They can be divided into three groups: children who accompany their parents in migration to Thailand; unaccompanied migrant children; and children born to migrant parents in Thailand (Huguet/ Punpuing 2005: I24).

The liminal legal status of migrants leads to specific kinds of vulnerability that significantly affects their experiences of assimilation in Thailand in general, and their attitude towards education in particular. Burmese children born to migrant parents in Thailand cannot obtain citizenship of either Myanmar or Thailand. Myanmar law requires a child born to Burmese parents to be registered within a month of birth. Parents must use the birth certificate to apply for a household certificate. Burmese migrant parents cannot fulfil this requirement while working in Thailand since many undocumented migrant parents may have left Myanmar without a proper document or they may be afraid that if they return, their re-entrance to Thailand could be difficult and costly.

Most workers from Myanmar are reported to have a Myanmar ID, but in order to legally leave the country they also need to have a passport, which is also very costly. Therefore, many migrants from Myanmar leave their country illegally, even though returning without a proper document may lead to a penalty of up to one year's imprisonment and a fine (Rukumnuaykit 2009: IO-II). As a matter of principle, Thai nationality may be obtained by birth for all children born in Thai territory but according to Thai law undocumented migrants are exceptions to this principle (Yang 2007: 523). Without Thai or Burmese citizenship, these children are left stateless, and are what Bhabha calls "Arendt's children", a situation when 
"supposedly inalienable rights are unenforceable for individuals who lack their government" (Bhabha 2009: 4II). Bhabha has further observed that, according to Article I.I of the Convention Relating to the Status of Stateless Persons of 28 September 1954, statelessness refers to when a person is "not considered as a national by any State under the operation of its law" (Bhabha 2009: 4II).

Though migrant children in Thailand are granted temporary status, their future is still very uncertain. There is no clear implication for their legal status after they complete basic education. This means that there is no clear expectation of obtaining Thai citizenship or permanent residency. Migrant children are subject to the same procedures as their parents in that they may only attain a temporary or precarious legal status. Due to their liminal legal status, job opportunities are limited to manual jobs, as restricted by the law. ${ }^{5}$ These jobs require no educational qualification, but workers who are proficient in Thai might have a better chance to work in a higher position with higher wages than workers who cannot speak Thai. The opportunity for Burmese labour migrants to legalize their residential status is further limited as the law requires that aliens must demonstrate 'good behaviour' (Thailand's Nationality Act B.E.2508 amended by Act B.E.2535 and Act B.E. 255I, Section IO.2). In practice, this excludes most migrants (as well as their children) who have entered the country illegally (Yang 2007: 526). Since there is no clear policy or prospect for the future of migrant children, migrant parents and their communities view the efforts of the government to provide education to their children with suspicion. Moreover, a series of shifts in immigration policies in the last decade have exacerbated their already insecure feeling about their future in Thailand and this significantly affects their attitude towards education.

The precarious status of migrant children as well as their families brings about ambiguity in their entitlement to education. As mentioned earlier, the state's decision to provide rights to education for migrant children is based on national security concerns, and the benefits of providing education to migrant chil-

5 Ekachai, Sanitsuda, 2003: Shattered Dream: Immigrant Workers' Fact and Figure, The Human Rights Sub-Committee on Ethnic Minorities, Stateless, Migrant Workers and Displaced Persons, The Lawyers Council of Thailand; at: <http://www.statelessperson.com/www/?q $=$ node $/ 607 \mathrm{I}>$ (accessed 2 May 20I2); and Thai Cabinet Resolution of 26 May 2009. dren are weighed against the costs of not providing it (ILO/OEC 2008: 8).

\subsubsection{Migrant Children's Education in Samut Sakhon}

While Samut Sakhon has been experiencing rapid growth, especially in the fishery sector, the province has employed a large number of migrant workers to take over low-skilled labour jobs that have been abandoned by local Thais. Since it is unlikely that Thai workers will return to these jobs, there is an expectation that Thailand, and especially the Samut Sakhon province, will continue to depend on migrant workers in many sectors, especially fishery and fishery-related industries. Hence, there have been some shifts, not only in migration policies, but also in relation to social welfare, and in particular to education and health care.

According to the registration statistics provided by the Ministry of Labour, in 2OII there were I,2I8 migrant children under fifteen years of age registered as dependants of migrant workers in Samut Sakhon. However, this number does not reflect the reality of migrant children since a short period of registration (I5 June-I4 July 20II), inadequate publicity about government registration, and complications with the system led to only a small number of children being registered. $^{6}$

The Labour Rights Promotion Network (LPN), an NGO working with migrant children in Samut Sakhon, estimates that every year there are 2,000 children born to migrant parents in Samut Sakhon. Furthermore, given that some children were sent home and some accompanied their family to other provinces in search of work, the estimated number of migrant children in Samut Sakhon who arrived between 2004 and $201 \mathrm{II}$ is 7,000-I0,000. ${ }^{7}$ This situation is further described by an official from the Education department:

We are aware of the 'Education for All Cabinet Resolution' which is the policy of the government that states that migrant children, regardless of their status, can go to school. Therefore we have tried to improve the situation of migrant children in our area. We have worked with our sample school, the Sirimongkol School, to promote the school enrolment of migrant children. We try to publicize this to inform the migrant parents that their

6 Interview by Kamowan Petchot with Sompong Srakaew, Organization Director at Labour Rights Promotion Network (LPN), Thailand in July-August 20II.

7 Interview by Kamowan Petchot with Sompong Srakaew. 
children can come to school. Most of them go to Sirimongkol School, our sample school. The number of migrant children enrolling in schools has increased over time although we still face problems of student drop-out. ${ }^{8}$

Table 17.1: Number of migrant students enrolling in the public school in Samut Sakhon during the academic years 2005-2009. Source: Samut Sakhon Educational Service Area (2012).a)

\begin{tabular}{|c|c|}
\hline Academic Year & No. of Migrant Students \\
\hline 2005 & 177 \\
\hline 2006 & 287 \\
\hline 2007 & 493 \\
\hline 2008 & 526 \\
\hline 2009 & 1,039 \\
\hline
\end{tabular}

a) Samut Sakhon Educational Service Area, 2012: "Number of Migrant Students Enrolling in Public School in Samut Sakhon from Academic Year 20052009"; at: <http://www.km.skn.go.th/?name= research \&file=readresearch\&id=27> (accessed 28 June 2012).

While the Samut Sakhon Educational Service Area has devoted a lot of attention to education for migrant children, policy implementation has also been driven and supported by international organizations such as the ILO's International Programme on the Elimination of Child Labour (ILO-IPEC), IOM, and Save the Children. These organizations operate their own projects as well as others in partnership with local organizations, both governmental (e.g. Samut Sakhon Educational Service Area) and non-governmental (e.g. LPN and the Rak Thai Foundation). The main objectives of these international organizations in Samut Sakhon range from education as a key mechanism for bringing children out of child labour (ILO/OEC 20IO) to education as a means of protecting children from trafficking and exploitation (Save the Children UK). As a result of the convergence of objectives and interests from various parties at the local, national, and international levels in providing educational opportunities for migrant children in Samut Sakhon, the educational situation of migrant children has improved. However, there still remain some challenges faced by schools, as well as barriers caused by migrant children's liminal status.

At the local level, schools have adopted different interpretations of the 2005 'Education for All' Policy,

8 Interview by Kamowan Petchot with Mr Pongdhep, Education Service Area Officer at Sirimongkol School, Thailand in July-August $201 \mathrm{I}$. resulting in different practices. At the same time, at the national level, there is a lack of effective coordination of priorities and interest between the different agencies that are involved in migrant management (e.g. MOE, MOI, MOL, and the Royal Thai Police). Ineffective communication and coordination between different agencies, such as MOE and MOI regarding students' ID numbers and budget allocation, exacerbates not only the vulnerability of uncertain status for migrant students, but is also a financial burden for schools.

\subsubsection{Tracking Differences and Commonality}

Migrant children have two main educational options, namely formal (public school) and informal (e.g. a migrant learning centre). The challenges these schools face in providing education for migrant children must be specially emphasized. Interviews were conducted in two public schools, one of which had a majority of migrant students while the other had a majority of Thai students. In addition, one migrant school/learning centre was selected for interview. There are many actors involved in the provision of education for migrant children, ranging from the staff of the schools, educational authorities, NGOs, and learning centres to communities. Data were collected from three main groups of stakeholders, namely teachers, students, and parents/guardians, with some additional interviews with education officials from Samut Sakhon Educational Service Area and NGO workers from LPN. The first school is the Wat Sirimongkol School, which provides education from preprimary to primary level (grade 6). There are 604 students: 59I migrants and ten Thai students. The school has the largest number of migrant students, with a cluster of more than thirty per cent of the migrant students who enrol in public schools in Samut Sakhon. It was also the only school where migrant students outnumbered Thai students. The openness of the school's policy allows for the registration of students regardless of their nationality and legal documents. This school has furthermore an ethnic affinity with the local community. The school is located in the old Mon-Thai community, which is quite open to newcomers from Myanmar. The community still shares some ethnic identity with the newcomer Mons, such as language, cultural practices, and beliefs, although they are also open to people of other ethnic groups as well. Most people in this community work in the agricultural sector. 
Table 17.2: Number of students at the primary and upper secondary levels in Samut Sakhon during the academic year 2010. Source: Ministry of Education (2012). ${ }^{\text {a) }}$

\begin{tabular}{|c|c|c|c|}
\hline Grade & Male & Female & Total \\
\hline $\begin{array}{l}\text { Grade } 1 \\
\text { Grade } 2 \\
\text { Grade } 3 \\
\text { Grade } 4 \\
\text { Grade } 5 \\
\text { Grade } 6\end{array}$ & $\begin{array}{l}3,779 \\
3,550 \\
3,584 \\
3,577 \\
3,501 \\
3,690\end{array}$ & $\begin{array}{l}3,578 \\
3,324 \\
3,336 \\
3,330 \\
3,253 \\
3,557\end{array}$ & $\begin{array}{l}7,357 \\
6,874 \\
6,920 \\
6,907 \\
6,754 \\
7,247\end{array}$ \\
\hline Total of Primary Ed. & 21,681 & 20,378 & 42,059 \\
\hline $\begin{array}{l}\text { Grade } 7 \\
\text { Grade } 8 \\
\text { Grade } 9\end{array}$ & $\begin{array}{l}3,762 \\
3,393 \\
3,038\end{array}$ & $\begin{array}{l}3,331 \\
3,272 \\
3,057\end{array}$ & $\begin{array}{l}7,093 \\
6,665 \\
6,095\end{array}$ \\
\hline Total of Lower Secondary Education & 10,193 & 9,660 & 19,853 \\
\hline $\begin{array}{l}\text { Grade } 10 \\
\text { Grade } 11 \\
\text { Grade } 12\end{array}$ & $\begin{array}{l}779 \\
699 \\
584\end{array}$ & $\begin{array}{l}1,272 \\
1,158 \\
1,027\end{array}$ & $\begin{array}{l}2,051 \\
1,857 \\
1,611\end{array}$ \\
\hline Total of Upper Secondary Education & 2,062 & 3,457 & 5,519 \\
\hline
\end{tabular}

a) Ministry of Education, 2012: "Number of Students at Primary-Upper Secondary Levels in Samut Sakhon: Academic Year 2010" (Bangkok: Government of Thailand); at: <http://www.moe.go.th/data_stat/\#\% E0\%B8\%82\% E0\%B9\% 89\%E0\%B8\%AD\%E0\%B8\%A1\%E0\%B8\%B9\%E0\%B8\%A5-\%E0\%B8\%AA\%E0\%B8\%96\%E0\%B8\%B4\% E0\%B8\% 95\%E0\%B8\%B4\%E0\%B8\%94\%E0\%B9\%89\%E0\%B8\%B2\%E0\%B8\%99\%E0\%B8\%81\%E0\%B8\%B2\%E0\%B8\%A3 \%Е0\%B8\%A8\%E0\%B8\%B6\%E0\%B8\%81\%E0\%B8\%A9\%E0\%B8\%B2> (accessed 28 June 2012).

The school receives funding from the Ministry of Education (MOE). The school had applied for a per head budget by sending the total number of students and school registration documents without applying for the thirteen-digit numbers for their students; the Ministry left this requirement to the discretion of the secondary school. The rationale behind this practice is the minimum age for legally working. If the school had applied for civil registration for their students, it might have contributed to a drop-out of students before grade 9. It was felt that some migrants might just have used school as a means to obtain civil registration and legal status in order to stay in the country, after which they would get the thirteen-digit number and take their children out to work. ${ }^{9}$

The school was popular among migrant students because of a flexible curriculum that adjusted to the specific needs of migrant children and provided a migrant-friendly environment. The school has used the core curriculum as assigned by the MOE, but has adjusted some details to suit migrant children's learning needs, such as providing a translator to help the teachers in primary classes so that new students can follow

9 Interview with teacher $\mathrm{G}$, a teacher from Sirimongkol School and teacher I, a teacher from LPN Learning Centre, 2OII. the class and gradually learn Thai. The school also has activities that help promote an understanding of Thai culture and values, and this can facilitate the children's integration into Thai society through such things as Thai etiquette and courtesy. The second school, the Srisuttharam School, is a big public school with 583 students, of whom I24 are migrants. The school provides education from pre-primary to lower secondary level (grade 9). The school is located in the same area and is functionally linked to the LPN Learning Centre, which trains and prepares migrant students to join this public school. The students from the learning centre who wish to continue their study in this school have to complete an examination to identify which class fits their academic ability.

The school has a legal duty to provide education to every child, regardless of their legal status. When a child with no legal registration documents enrols, the school registrar issues a personal record for the student, which includes a photograph and the parents' details. This school will also apply for a civil registration (the thirteen-digit ID numbers) for their students. The ID numbers allow for temporary residence up to a maximum of ten years. This school reported that the process of issuing an ID number from the MOI could be very slow, up to two years or more. The delayed procedure has caused budgetary challenges to 
the school because, for the per head budget from MOE, the school needs to send the actual number of enrolled students, with their thirteen-digit ID numbers attached. As a result, the school does not receive the per head budget for those students who are waiting for their ID numbers. As a result, the bureaucratic difficulties of receiving funding for migrant students is in contradiction with the school's legal duty to provide education for migrant children. As confirmed by the school's director:

My school receives the support from the government. When we accept migrant students, school registrar will fill the form for students' information and then send the application for the thirteen-digit number to the district office which will eventually go to the Ministry of Interior who will issue the ID for migrant students but the problem we have here is that sometimes, it takes so long before the students can get their numbers...sometimes up to two years. I'm not sure why it takes them so long. We need that number to apply for a budget per head from the Ministry of Education. We cannot get the budget for students who don't have an ID or are still in the process of applying so we have to share with them the budget of other students, Thai students and those students who already received their ID numbers...I think maybe the long and complicated procedure and financial problems might be one of the reasons why many public schools don't want to accept migrant students but here we accept all children who applied. The law clearly states that we have to do so. ${ }^{10}$

There are two ways for migrant children without legal residential documents to obtain some form of legal status, through their registration as dependents of migrant workers and/or through registration by the school. If migrant children apply through schools, they will be granted a different status and a longer temporary residence permit of up to ten years, while registering as a dependent will grant them the same status as their parents, with a residence permit for up to two years. Mostly, migrants can only obtain a oneyear amnesty to legally stay in the country through a work permit renewal with the MOL. Accordingly, a number of migrant parents have decided to send their children to a public school to obtain a longer legal status.

Migrant children without ID numbers face arrest and deportation, and they are charged with entering the country illegally. However, if the migrant children are students of a public school, whether children who have not applied for an ID number, or those who

10 Interview by Kamowan Petchot with Mr Pisarn, School Director, at Srisuttaram School, Thailand in July-August $20 I I$. were waiting for one, then their teachers may provide the police with evidence that they are students in order to get them out of custody. Some migrant parents send their children to school just to obtain the legal status, for fear of police harassment, arrest, and deportation.

I and most parents send our children to school because we are afraid that the police could arrest our children. Now we are mostly registered at the new registration this year so police cannot arrest us any more but for many children who did not know about the registration or the employer did not take them to registration, they still have no documents. But if children come to school, the police cannot arrest them. ${ }^{11}$

Besides the budgetary challenge faced by Srisuttharam School due to the delay in issuing ID numbers, the school also experiences the problem of student dropout. Many students have to move when their parents change jobs, and this makes it difficult for students to continue their studies as they might leave before they receive the ID card, and they cannot reapply for it from the new school. Public schools are only open for enrolment twice a year, at the beginning of each new semester, while the pattern of mobility of migrant families varies throughout the year. Migrant children might arrive in the middle of the school semester, and be unable to immediately continue their study in a new school, or may end up repeating classes. Poverty and debt was mentioned by those interviewed as the main factor that caused students to drop out. ${ }^{12}$ Another teacher emphasized this point:

Basically, learning Thai is important since they live here but some of their parents don't think like that. They don't think about how useful an education for their kids is nor do they pay any attention. However, there are some that care about the education of their children and send their kids to school although there are a lot of problems due to the expenses, for example for school uniform, daily allowances, transportation, etc. Even if they don't have to pay tuition fee, but for some, still out of hand. In this classroom as well, there are many poor kids whose parents work for a shrimp peeling factory. Some families have only a mother who is living with the children while the father has sailed with the fishing boat. Many children left school to work. ${ }^{13}$

11 Interview by Kamowan Petchot with A, a migrant parent at Srisuttaram School in July-August 20II.

12 Interview by Kamowan Petchot with Vava, a student, with teacher W, and with Mr F at Srisuttaram School, Thailand in July-August 20II.

13 Interview by Kamowan Petchot with Tan, a teacher, at LPN Learning Centre, Thailand in July-August $20 I I$. 
Even though there was no school fee and there were subsidies for uniforms and textbooks, parents still have to pay some additional expenses such as transportation costs and a daily allowance. The income of some migrant families is too low for them to be able to afford their children's education. To send a child to school, parents have to spend at least 300 baht for their lunch and at least 500 baht on transport every month, while the average monthly income of a worker in the seafood processing factories is about 2,000 baht. When added to other necessary expenses such as housing and food, the educational expenses are beyond the financial means of migrant families. Apart from their low income, many migrant families are also in debt bondage, arising from their journey across the border and sometimes through job seeking, as was confirmed by one migrant child:

When I first arrived here, I joined school but my mother and brother alone cannot work to pay our debt so I left school to work in the shrimp peeling factories...Then when we paid off all our debt I came back to study in school. ${ }^{14}$

Many children leave school to enter the labour market when they reach the age of nine or ten years old, either by working in the informal sector, or by lying to employers about their real age, since the minimum age for employment in Thailand is fifteen. This correlates with the drop-out rate of students in school. According to statistics from the Samut Sakhon Educational Service Area for the academic year 20I0, the educational level that had the highest drop-out rate was grade 2, where a total number of forty-six students became only ten students, who proceeded to grade 3 .

A third school for migrants was set up five years ago by LPN and it is solely funded by foreign donors. Currently there are I40 migrant students in the learning centre, ranging from pre-primary to primary level (grade 2). The majority of the migrant children are Burmese and Mon from Myanmar. As mentioned, the learning centre is linked to the Srisuttaram School, both institutionally and by location, at the back of the Srisuttaram School. Their classes prepare migrant students to enter the public school system. The school tries to create a public school environment, such as requiring students to wear a uniform, as well as singing the national anthem, praying every morning, and using the same curriculum and textbooks. Although the

14 Interview by Kamowan Petchot with Min, a migrant student at Srisuttaram School, Thailand in July-August 2OII. learning centre uses the same curriculum as the public school, they are more flexible and sensitive to the situations and specific needs of migrant children. The main language of instruction is Thai with some additional use of Burmese and Mon so that the new students can follow the lesson and don't feel isolated from their classmates.

Sending children to the learning centre rather than the public school involves additional costs. Although the centre does not require a school fee, parents still have to cover transport costs, lunch, uniforms, textbooks, and stationery. Despite this, parents still prefer to send their children to the learning centre before they enter the Thai public school in order to prepare their children mentally and academically for the formal school system. The Thai public schools provide no preparatory classes for migrant students. Furthermore, the learning centre has a more flexible acceptance period for new students, which better suits the pattern of migrant families' mobility. They accept new students all year round. Although many people call the LPN school a migrant school, the law does not recognize its status as a school. For this reason, the school receives no support from the government. Lack of support from government poses the main challenge. The school does not require a school fee as all school expenses come from foreign donors. However, it is running out of funds after five years of external support and is facing difficulties in operating. The school has already had to cut many expenses. Free lunches have been cancelled, while textbooks and some stationery have been scarce. Moreover, the lack of funding leads to a lack of teachers. Apart from financial difficulties, the status of teachers in the learning centre is another issue. The learning centre has a problematic status. Teachers in the learning centre are considered to have a lower status than teachers in formal schools. They also receive lower wages, are seen as having lower social status, and there is no legal recognition of their status. As a result, people who are qualified for the job would prefer to work for formal schools.

\subsubsection{Impact of 'Liminal Legality' on the Experience of Migrant Children in the Thai Education System}

The 'liminal legality' of migrant children and their families affects the experiences of children in the education system. The combination of immigration laws, migrant children's socio-economic status, and their parents' preferences affect both migrant children's 
educational lives and by extension their incorporation into Thai society.

Most migrant children are living in 'mixed legal status' families, where each family member has a different status in terms of the immigration law (Fix/ Zimmerman 200I). Registered migrants possess a temporary amnesty from deportation. However, the registration which allows undocumented migrants to temporarily stay and work in Thailand involves multiple and confusing deadlines, which are often not well communicated to the migrants. Migrant children who apply for an ID number through the school are granted a temporary residence permit of not more than ten years, whereas registered parents and dependants are granted a residence permit and a work permit of no more than two years.

Sometimes one family has members with both statuses in relation to the law. For example, a migrant child might live in a family where one of the parents is registered while the other is unregistered, or had been registered at an earlier stage but fell back into irregularity. At the same time, migrant children may have siblings who are too young to join school and register through the school system, and thus still do not have a legally-protected status. Among migrant children, some have received the ID number through the school, while others will have been on a waiting list for years before they receive their ID number. A further group of migrant children cannot apply through their school since not all primary schools concern themselves with the registration of their students, but leave the burden to secondary schools.

Living in the grey area of precarious legal status, the mixed status of migrant children leads to sceptical attitudes toward education, and this further impacts on the long-term opportunities of migrant children. As parents and other guardians move in and out of legality and fear deportation, their children and their children's education are also affected. For example, some parents feel that contact with a state authority, like a public school, can lead to an inquiry about their legal residence status, and therefore prefer to send their children to learning centres, which generally provide only a basic education up to primary or lower secondary level. Alternatively, parents choose to end the education of their children altogether at the basic level due to their fear of contact with government authorities. Consequently, as migrant parents do not perceive a secure future in Thailand, they are reluctant for their children to engage in the Thai education system. The concern of parents is that, following their education, their children will end up in the same situ- ation as themselves, with a 'liminal legal status' and access to the same low-paid jobs. ${ }^{15}$ Another migrant parent elaborated on this point:

I think it is very good that my granddaughter goes to school. Now she speaks Thai much better than before and she can read signs on the street and medicine labels for me. [When asked: What did she plan for her granddaughter's education? How long does she plan to keep her grandchildren in school?] No, I don't want her to stay in school for too long...maybe not more than Por 3 [Prathom 3, first level of elementary school equivalent to grade 3]...or Por 6 [Prathom 6, second level of elementary school equivalent to grade 6]. I don't work any more these days ... Only their parents earn for the whole family now and if they have to change workplace or if we have to go back to Myanmar, she will have to get out of school anyway. It is better that after she gets necessary skills, she works to earn and help her family. ... [After a long pause] Even if she finishes high school, she will work like her parents. That doesn't require a school certificate. ${ }^{16}$

Moreover, frequent shifts in immigration law and other regulations lead to an uncertain feeling among both parents and children about their future in Thailand, as deportation back to their country of origin can happen at any time. Consequently, there has been a trend towards taking children out of schools as parents weigh the possible gains from education in the future against the likely income from child labour, since they do not have a secure feeling anyway about their future in the country, including that of their children.

This is also partly a result of the experiences of migrants in their country of origin. One respondent recalled her mother telling her of the situation of underemployment in Myanmar; this leads to attitudes to the value of education, which are different from that of Thai society, where a higher level of education is valued as providing better opportunities in the labour market. ${ }^{17}$

For some parents with previous experiences in Myanmar, a higher level of education does not necessarily translate into better-paid jobs since the economy

15 Interview by Kamowan Petchot with Mrs S, a migrant parent, at LPN Learning Centre, Thailand in JulyAugust 20II, and interview by Kamowan Petchot with Yu, a student at Srisuttaram School, Thailand in JulyAugust 20II.

16 Interview by Kamowan Petchot with Mrs S, a migrant parent, at LPN Learning Centre, Thailand in JulyAugust 20II.

17 Interview by Kamowan Petchot with Vava, a student, at Srisuttaram School, Thailand in July-August $20 I I$. 
does not offer this and the majority of migrants face unemployment or underemployment. The parents' level of education and length of time in Thailand also makes a difference in their attitude towards the value of education, since parents who have more education and have lived for a longer period of time in Thailand tend to value education more than just language literacy and tend to keep their children in schools for longer:

I want my son to get an education as high as he could... I have been here for a long time (more than 15 years). I have seen things and know more than others [migrant parents] who work in seafood factories here. I know that the school is good for my son's future. He will have a better opportunity, a better future than others without education. Many migrant parents don't think like me. They just want their children to have basic Thai language and keep their young children at school so that the teachers can take care of their children while they go to work. But I want my son to go to school and maybe to university and get a nice job. ... But this also depends on the government. ${ }^{18}$

Mr. Mihn has been in Thailand for fifteen years and employs people in his own shop. His situation is different from many other migrant parents who mostly work in fishery or fishery-related factories and have been in Thailand for less than ten years. Therefore his financial situation is also better than that of most other migrant parents. The family lives in a rented house while most migrant families live in rented shared rooms in an apartment.

Immigration law restricts migrants to remaining in the area where they have registered; movement out of that area without the permission of the authorities is a violation of the law. As a result, many families are separated and are not able to meet each other often. Most migrant children in Thailand have had experience of family separation, both in relation to family members who still live in their country of origin, and of the separation caused by immigration laws that restrict the freedom of movement of migrants, as well as the deportation of some family members who lack (or lose) their regular legal status. Family separation can have an important impact on the performance of migrant children in school as well as their integration into Thai society. In short, immigration law dictates whether migrants will have access to education or not, and to what level. By extension, immigration law shapes migrants' expectations and goals.

18 Interview by Kamowan Petchot with Mihn, a migrant parent, in Thailand (place withheld) in July-August $201 \mathrm{I}$.
A further important factor affecting migrant children's access to schools is their insecure financial situation. Even though education is provided by the state free of charge, parents need to pay additional direct and indirect costs of education, such as transport and daily allowances, which can be considered unaffordable for low-income migrant families. Migrant families are bound by their 'liminal legality'. Due to their inability to find better-paid jobs, a lack of negotiating power to improve their wages, and the need to pay high registration fees, migrant families also face economic difficulties. Without access to other resources, children are sometimes forced to enter the labour market in order to support their families. The opportunity cost of child labour outweighs the value of receiving an education, particularly when families are in debt, acquired through making the journey to Thailand or sending remittances to other family members back home.

The socio-economic status of migrants is the most significant factor that dictates access to education and that shapes the opportunity structure in the education system. This is exacerbated by an uncertain legal status, which itself moulds migrants' access to financial resources (for example, funding for education, and bank loans). Without access to financial resources, migrant children are pushed into child labour. Marginal legal status also shapes their interpretation of opportunities in the market, of school and of the education system in general.

Apart from the household composition and the financial situation of migrant children, their parents' preference determines the access to education of migrant children. Parents decide the type of education (formal, informal, or non-formal education), schools, duration of time in school, and level of education their children should receive.

As mentioned earlier, migrant families feel insecure about their future in Thailand due to their precarious status and frequent shifts in immigration policy. As a result, they adjust their educational aspirations to their life conditions. Their expectation from education is mainly oriented to acquiring basic skills, such as rudimentary mathematics and language literacy for the purpose of communication in the workplace and everyday life, rather than aiming at attaining a degree certificate or level of education higher than their basic communication needs.

However, as mentioned earlier, there is an exception to this general trend. Parents who have received a higher level of education or have spent several years in Thai schools tend to recognize the value of educa- 
tion more, and tend to keep their children in school for a longer period. This group of parents has developed higher aims for and expectations from the education of their children. They believe that, with a higher level of education, their children will be able to find better jobs at a skilled level, which will lead them out of poverty and to a better future. However, parents still expressed concerns about the frequent shifts in policies and their uncertain future and recognize that their 'liminal status' serves as a barrier preventing them from access to educational loans or bank loans in order to pay for a higher level of education. One of the prior conditions in requiring an educational loan is Thai nationality, a condition which migrant children lack.

Schools and teachers seem to ignore the situation of migrant children at home as well as ignoring the specific need as migrants who have to live with an uncertain legality:

We use the core curriculum as assigned by the Ministry of Education. Here we don't adjust the curriculum to the student. The student must adapt themselves towards us. We treat them just like Thai students. Everything is equal. ... Here we only use Thai. ... Everything is the same, no divide... If they violate school rules they will be punished just like Thai students. ... Some [migrant] students often come to school late or missed classes often. ... [When asked about differences in performances between Thai and migrant students] They are good at mathematics and English but most of them are bad at science or social study, those subjects that require Thai language skills. They will be quiet but they are diligent and obedient students. ${ }^{19}$

Meanwhile, a school official responded:

Of course, I think it [the class and curriculum] is very useful and appropriate for them. I don't think we have to adapt to their needs. I think it's them that need to adapt to our curriculum because they get many benefits from coming to school. ... It's them who benefit from coming to school so they need to adjust themselves to school rules as well as to the curriculum. ${ }^{20}$

This lack of consideration about the effect of an uncertain legal status on the performance and educational objectives of migrant children leads to a feeling of isolation or exclusion in migrant children at school, and this can form an additional reason for children to drop out of school.

19 Interview by Kamowan Petchot with Noi, a teacher, at Srisuttaram School, Thailand in July-August 201 II.

20 Interview by Kamowan Petchot with an Education Service Area Officer at Sirimongkol, Thailand in July-August $20 I I$.
In summary, while education is made available to migrant children by way of government policy, migrant children's lack of access to education is due to their problematic legal status. Legal status reinforces and exacerbates the negative impacts of other forms of discrimination such as race, gender, and socio-economic status.

\subsection{Conclusion}

The Thai government has made an effort to ensure the availability of education by granting free and compulsory education for every child within its territory, and has tried to reduce discrimination against migrant children by requiring that schools accept all children regardless of their legal status. However, discrimination still takes place through the implementation of this policy, where migrant children are prevented from accessing education for various reasons. Discrimination is mainly based on the 'liminal legal status' of migrant children.

Because of the long bureaucratic procedure in applying for a budget for migrant children, many schools face financial difficulties. This procedure discourages most schools from accepting migrant students, and leads to a concentration of migrant children in a few schools. In addition, insensitivity on the part of schools to migrant children's difficult socioeconomic conditions and their specific needs, such as language barriers, leads to formidable challenges for schools in providing quality education. Furthermore, learning centres with an unrecognized status receive no support from government and face even more significant financial problems, including the low wages and status of teachers, and ultimately an even lower quality of education. However, 'liminal legality' is the main factor preventing children from enjoying their rights to education, by shaping migrant children's experiences in the education system as well as their educational aspirations, and in general shaping the opportunity structure of migrant children in education. This can also explain the low enrolment rate of migrant children in public schools and their early dropout rate. This situation of 'liminal legality' not only affects the educational opportunities for migrant children, but also has significant implications for their integration into Thai society. Without addressing the problematic legal status of migrant children, it will be impossible for migrant children to fully realize their right to education. 


\section{References}

Bailey, Adrian; Wright, Richard; Mountz, Alison; Miyares, Ines, 2002: "(Re)producing Salvadoran Transnational Geographies", in: Annals of the Association of American Geographers, 92,I: I25-I44.

Bhabha, Jacqueline, 2009: “Arendt's Children: Do Today's Migrant Children Have a Right to Have Rights?", in: Human Rights Quarterly, 3I,2: 4IO-45I.

Calavita, Kitty, I998: "Immigration, Law and Marginalization in a Global Economy: Notes from Spain”, in: Law \& Society Review, 32,3: 529-566.

Caouette, Therese, 200I: "Small Dream Beyond Reach: The Lives of Migrant Children and Youth along the Borders of China, Myanmar and Thailand', A Participatory Action Research Project, Save the Children (UK); at: <http://www.childmigration.net/STC_Caouette_O2> (I5 July 20II).

Chantavanich, Suphang 2007a: "Thai Policies Towards Migrant Workers from Myanmar", Paper presented at the APMRN Conference at Fujian Normal University, Fuzhou, 26-28 May.

Chantavanich, Suphang, 2007b: "Factors Affecting Thailand Immigration Policies During I992-2004', Paper presented at the Conference on International Migration, Multi-local Livelihoods and Human Security: Perspectives from Europe, Asia and Africa at the Institute of Social Studies, the Hague, 29-30 August.

Convention on the Rights of the Child, I989: Passed by the UN General Assembly on 20 November 1989, UN Treaty Series, I577: 3.

Coutin Susan, 2002: Legalizing Moves: Salvadoran Immigrants' Struggle for U.S. Residency (Ann Arbor: University of Michigan Press).

Freeman, Gary, 2004: "States and Modes of Political Incorporation: Immigrant Incorporation in Western Societies", in: International Migration Review, 38,3: 945969.

Fix, Michael; Zimmerman, Wendy, 200I: "All Under One Roof: Mixed Status Families in an Era of Reform', in: International Migration Review, 35,2: 397-4I9.

Goldring, Luin; Berinstein, Carolina; Bernhard, Judith, 2009: "Institutionalizing Precarious Migratory Status in Canada”, in: Citizenship Studies, I3,3: 239-265.

Huguet, Jerry; Punpuing, Sureeporn, 2005: "Child migrants and children of migrants in Thailand", in: Asia Pacific Population Journal, 20, 3: I23-I42.

ILO (International Labour Organization); OEC (Office of Education Council), 2006: Research study on Educational opportunity of migrants and stateless children in Samut Sakhon; at: <http://www.ilo.org/public/english/ region/asro/bangkok/apec/download/th_study_edu. pdf> (II April 20II).

ILO (International Labour Organization); OEC (Office of Education Council), 2008: Education Provision for Stateless and Cross National Migrant Children in Thailand.
ILO (International Labour Organization), 20I0: Good practice notes: Serving the unserved: How government agencies and $\mathrm{NGOs}$ learned to reach migrant children with educational opportunities, at: <http://www.ilo. org/global/topics/WCMS_I42095/lang-en/index.htm> (I2 September 20II).

IOM (International Organization of Migration), 2008: Situation report on international migration in East and South East Asia, at: <http://www.iom.int/jahia/webdav/ site/myjahiasite/shared/shared/mainsite/published_ docs/books/IOM\%20Situation\%20Report $\% 20-\% 20$ Final.pdf> (I5 June 20II).

Martin, Philip, 2004: Thailand: Improving the Management of Foreign Workers, Bangkok: International Labour Office and International Organization for Migration.

Martin, Philip, 2007: The Contribution of Migrant Workers to Thailand: Towards policy development, Bangkok: International Labour Organization; at: <http://phamit. org/download/Migrants\%2oeconomic\%2ocontribution. pdf> (I4 June 20II).

Menjivar, Cecilia, 2006: "Liminal Legality: Salvadoran and Guatemalan Immigrants' Lives in the United States”, in: American Journal of Sociology, III,4: 999-I037.

MFA (Ministry of Foreign Affairs), 20Ir: Right to Education for Migrants, Refugees and Asylum Seekers, Bangkok: Government of Thailand; at: <http://www.mfa.go. th/ humanrights/index.php?option=com_content\&view= article\&id $=72$ :right-to-education-for-migrants-refugeesand-asylum-seekers- $\&$ catid $=35$ :un-resolution $\&$ Itemid $=73>$ (2 May 20I2).

Muntarbhon, Vitit, 2005: The Mekong Challenge - Employment and Protection of Migrant Workers in Thailand: National Law/Practices Versus International Labour Standard, International Programme on the Elimination of Child Labour, Bangkok: International Labour Office.

Pollock, Jackie; Pearson, Ruth; Kusakabe, Kyoko, 2009: "Policy Brief and Recommendation on Undocumented Labour Migration in Thailand", Paper presented at the International Workshop on Gender, Migrant Workers and Citizenship in the Greater Mekong Sub-region at the Asian Institute of Technology, Pathumthani, I-3 June.

Portes, Alejandro; Zhou, Min, I993: "The New Second Generation: Segmented Assimilation and its Variants", in: The Annals of the American Academy of Political and Social Science, 530,I: 74-96.

Portes, Alejandro; Zhou, Min, I993: 'The New Second Generation: Segmented Assimilation and its Variants', in: The Annals of the American Academy of Political and Social Science, 530, r: 74-96.

Rukumnuaykit, Pungpond, 2009: A Synthesis Report on Labour Migration Policies, Management and Immigration Pressure in Thailand, Geneva: International Labor Organization, at: <http://www.ilo.org/asia/whatwedo/ publications/WCMS_IO3923/lang-en/ index.htm> (7 August 20I2). 
Thai Cabinet Resolution of 26 May 2009, 'Registration of Irregular Migrants from Myanmar, Laos and Cambodia' (in Thai); at: <http://www.cabinet.soc.go.th/soc/ Program2-3.jsp?top_serl=220064\&key_word=\&owner_ dep $=\&$ meet_date_dd $=268$ meet_date_mm $=5 \&$ meet_da te_yyy $=2552 \&$ doc_idI $=\&$ doc_id $2=\&$ meet_date_dd $2=\&$ meet_date_mm2=\&meet_date_yyyy2=> (I5 May 20I2).

Thu, Zeya, 2006: "Migrant Children's Access to Education in Thailand: A Case Study of Myanmar Children in Samut Sakhon Province”, Masters thesis (Bangkok: Chulalongkorn University).
Turner, Victor, 1967: The forest of symbols: Aspects of Ndembu ritual (Ithaca: Cornell University Press).

Vasuprasat, Pracha, 20Io: Agenda for labour migration policy in Thailand: Towards long-term competitiveness, International Labour Organization/Japan Project on Managing Cross-border Movement of Labour in Southeast Asia, Regional Office for Asia and Pacific.

Yang Bryant, 2007: "Life and death away from the golden land: The plight of Burmese migrant workers in Thailand", in: Asian-Pacific Law and Policy Journal, 8,2: $486-535$.

Open Access. This chapter is distributed under the terms of the Creative Commons Attribution Non-commercial License, which permits any noncommercial use, distribution, and reproduction in any medium, provided the original author(s) and source are credited. 